\title{
Relationship between Sports and Quality Education among Secondary School Students
}

\author{
Alade, T. T. Ph D, Bamidele, T. O, Owoeye, S. T. \\ Department of Human Kinetics and Health Education, Bamidele Olumilua University of Education, Science and Technology, \\ Ikere-Ekiti (BOUESTI)
}

\begin{abstract}
The study investigated relationship between sports and quality education among secondary school students. The researchers used survey design of the descriptive type of research for the study, the research instrument used for this study was a self-structured closed ended questionnaire designed by the researchers. Inferential statistics of Pearson's Product Moment Correlation (PPMC) was used to test the hypotheses postulated at 0.05 level of significance. The researchers affirmed that there was a significant relationship between sports and class attendance, also it was established that there was a significant relationship between sports and educational aspiration among secondary school students' in Ondo State. The researchers recommended that, there should be orientation programme organized for secondary school students in order to make them understand the benefits of participating in sports, state government should give scholarship to students who participate in sports so as to motivate and encourage them for better and greater educational aspiration.
\end{abstract}

Keywords: Attendance, Aspiration, Class, Sports, Quality education.

\section{INTRODUCTION}

S ports are generally recognized as activities which are based on physical athleticism or physical dexterity. Sports are generally understood to include physical activities that go beyond competitive sports. Also sport is all forms of physical activity that contribute to physical fitness, mental well-being and social interaction. Sports is all forms of usually competitive physical activity which, through casual or organized participation, aim to use, maintain or improve physical ability and skills while providing entertainment to participants and in some cases, spectators (Peter-Ajayi et al, 2019)

Quality education through sports is an essential tool for achieving a more sustainable world. This was emphasised at the UN World Summit in Johannesburg in 2002 where the reorientation of current education systems was outlined as key to sustainable development. Education for sustainable development through sports promotes the development of the knowledge, skills, understanding, values and actions required to create a sustainable world, which ensures environmental protection and conservation, promotes social equity and encourages economic sustainability (Elaine, 2008). Sports is a powerful tool for promoting important human values such as respect for rules and for others, teamwork, discipline, diversity, hospitality and empathy. By leveraging its social cohesion capabilities, sports can be used to instill these values into young people and curb youth restiveness.

A sport is also an important enabler of sustainable development. We recognize the growing contribution of sports to the realization of development and peace in its promotion of tolerance and respect and the contributions it makes to the empowerment of women and of young people, individuals and communities as well as to health, education and social inclusion objectives (Lemke, 2016).

Students' participation in sports competition is known to contribute to the developmental outcomes for quality education, where children learn about physical, social and cognitive skills. Bamidele (2016) opined that engagement in sports is recognised to contribute a range of positive outcomes, specifically; physical and mental health, social wellbeing, cognitive and academic performance.

In the opinion of Haroona et.al (2018) sports participation improves mental health which in turn results to improved academic achievement. Therefore, sports is the most important part of a person's life that will help them develop as a person, getting educated citizens helps to develop the country because when the country have smarter people in the workforce, then things may run smoother and develop better.

There has been a lot of criticism about the extensive time students spend in sporting activities. Some people argued that schools should be in the business of ensuring quality education to secondary school students and not be so concerned about their social and emotional lives. The influence of sports in ensuring quality education of students cannot be over-looked if schools and parents really care about the mental fitness and academic excellence of secondary school students (Peter-Ajayi et al, 2020).

Bamidele (2016) is of the opinion that sports is all forms of physical activity that contribute to physical fitness, mental well-being and social interaction. These include: play; recreation; organized, casual or competitive sport; and indigenous sports or games. There is a widely spread belief in our country that sport participation, by its positive effects, contributes to better academic performance of students' within school setting. It was on this note the researchers intends to investigate the relationship between sports and quality education among secondary school students. 


\section{OBJECTIVES OF THE STUDY}

The specific objectives of this study are as follows:

1. To examine the relationship between sports and class attendance of secondary school students in Ondo State.

2. To examine the relationship between sports and educational aspiration of secondary school students in Ondo State.

\section{Hypotheses}

The following hypotheses were tested at 0.05 level of significance

1. There is no significant relationship between sports and class attendance of secondary school students in Ondo State.

2. There is no significant relationship between sports and educational aspiration of secondary school students in Ondo State.

\section{METHODOLOGY}

The researchers used survey design of the descriptive type of research for the study. This is because it gave the researchers the opportunity to elicit the needed information from the respondents. The population of the study consisted of all secondary school students in Akure South Local Government Area of Ondo State. Both male and female students were considered as population target for the study. The total population of public secondary schools students' in Akure South local government area of Ondo State is forty three thousand, six hundred and forty four $(43,644)$. There are twenty one thousand five hundred and eight $(21,508)$ male students and twenty two thousand one hundred and thirty six $(22,136)$ female students (Source: Ondo State Ministry of Education, 2019). It is from this population that the number of respondents needed for the study was selected.

The sample size of one thousand two hundred (1200) students was used for the study. The respondents were the students from public secondary schools in Akure South local government area of Ondo State. The simple random sampling technique was used to select fifteen (12) secondary schools out of the twenty seven (27) secondary schools in the local government area. Also non proportionate stratified sampling technique was used to select respondents across the five schools. The selection of respondents cut across both male and female students from SSS I, SSS II and SSS III.

The research instrument used for the study was a selfstructured closed ended questionnaire designed by the researchers that contained two sections of Yes/No formats with six (6) items under each section. A draft of the questionnaire was prepared by the researchers and given to two (2) experts in the field of Human Kinetics and Health Education to go through in order to establish face and content validity.
Reliability of the instrument was ascertained using split half method. The data collected was analysed by using inferential statistics of Pearson's Product Moment Correlation (PPMC) and Spearman Brown's formular. The co-efficient obtained was 0.98 .

The completed questionnaire by respondents was gathered and analyzed using both descriptive and inferential statistics. Inferential statistics of Pearson's Product Moment Correlation (PPMC) was used to test the hypotheses postulated at 0.05 level of significance.

\section{RESULTS}

Hypotheses 1: There will be no significant relationship between sports and students class attendance.

Table 1: PPMC analysis showing the relationship between sports students class attendance

\begin{tabular}{|c|c|c|c|c|c|}
\hline Variables & $\begin{array}{c}\text { No of } \\
\text { cases }\end{array}$ & Df & $\begin{array}{c}\text { Calculated } \\
\text { r-value }\end{array}$ & $\begin{array}{c}\text { Critical r- } \\
\text { value }\end{array}$ & Decision \\
\cline { 1 - 4 } Sports & \multirow{2}{*}{300} & 4 & 2.2396 & 0.950 & $\mathrm{~S}$ \\
\cline { 1 - 2 } $\begin{array}{c}\text { Class } \\
\text { attendance }\end{array}$ & & 4 & & \\
\hline
\end{tabular}

$\mathrm{P}<0.05$ (significant)

Table 1 shows the Pearson Product Moment Correlation analysis of relationship between sports and quality education in achieving sustainable national development. The $r$ calculated value of 2.2396 was positive and higher than the critical r-value of 0.0950 at 0.05 level of significance. Since the calculated $r$-value was higher than critical $r$ value, hypothesis 1 which stated that there will be no significant relationship between sports and quality education in achieving sustainable national development was rejected. This implies that there was a relationship between sports and students class attendance

Hypothesis 2: There is no significant relationship of sports and educational aspiration of secondary school students

Table 2: PPMC analysis of relationship between sports and educational aspiration of secondary school students

\begin{tabular}{|l|l|l|l|c|c|}
\hline Variables & $\begin{array}{l}\text { No of } \\
\text { cases }\end{array}$ & Df & $\begin{array}{l}\text { Calculated } \\
\text { r-value }\end{array}$ & $\begin{array}{l}\text { Critical r- } \\
\text { value }\end{array}$ & Decision \\
\cline { 1 - 5 } Sports & \multirow{2}{*}{300} & 4 & 1.229 & 0.950 & $\mathrm{~S}$ \\
\cline { 1 - 2 } $\begin{array}{l}\text { Class } \\
\text { attendance }\end{array}$ & & & & & \\
\hline
\end{tabular}

$\mathrm{P}<0.05$ (significant)

Source: Field survey (2016)

Table 2 shows the Pearson's product moment correlation analysis of relationship between sports and educational aspiration of secondary school students. The r-calculated value of 1.229 was positive and higher than the critical $r$-value of 0.0950 at 0.05 level of significance. Since the calculated $r$ value was higher than critical $r$-value, hypothesis 2 which stated that there is no significant relationship between sports and class attendance of secondary school students was rejected. This implies that there was relationship between 
sports and educational aspiration of secondary school students.

\section{DISCUSSION}

The result from hypothesis 1 shows that there is a relationship between sports and students class attendance. The result was in line with the assertion of Lemke, (2016) who in his contribution opined that sport often provides safe environments at the grassroots and community levels, at which participants are brought together in the pursuit of common goals and interests; learn values of respect, tolerance and fair play; and develop social competencies. The result of the study also supported the finding of Haroona et.al (2018) who posited that sports participation improves mental health which in turn results to improved academic achievement. Therefore, sports is the most important part of a person's life that will help them develop as a person, getting educated citizens helps to develop the country because when the country have smarter people in the workforce, then things may run smoother and develop better. The finding of the study also supported the view of Bamidele (2016) who asserted that Sports activity programmme provide valuable lessons for practical situations - teamwork, sportsmanship, winning and losing, and hard work. Through participation in active sports programme, students learn self-discipline, build selfconfidence and develop skills to handle competitive situations. But it is only when the students is ready and has intention to learn that is when it can help class attendance and improve students' performance. Students who participate in sport activity programme tend to have higher grade-point averages, better attendance records, lower dropout rates and fewer discipline problems than students generally.

The result from hypothesis 2 also revealed that there is a relationship between sports and students educational aspiration. The finding of the study concurred with the finding of Dyer et.al (2017). They opined that organized sports participation and physical activity have been positively related to academic achievement and improved school performance. High school sport involvement has the potential to enrich every individual participant's overall educational experience, while ensuring that his or her academic success is always viewed as the highest priority. The result also supported the view of Stucko, (2018) who opined that participation in organised sports has historically been viewed as a means of integrating students into both the school as an organization, and into society as a whole. A popular topic that has been debated is whether or not participation in competitive sports programme at the secondary school level has the potential to develop the participants' behavior, achievements and character in other areas of their lives beyond just their field of play. It can be reasoned that through interscholastic participation in athletics, positive outcomes can be seen in student-athletes' educational aspirations, academic achievement and character building. Secondary schools must stress that active involvement in an extracurricular activity is an honour and opportunity that is granted only to students who first fulfill their academic obligations, and meet eligibility standards.

\section{CONCLUSIONS}

Based on the findings from the study the researchers concluded that there is a relationship between sports students class attendance, also it was concluded that there is a relationship between sports and educational aspiration of secondary school students. The researchers recommended that there should be orientation organised for secondary school students in order to make them understand the benefits of participating in sports, state government should give scholarship to students who participate in sports so as to motivate and encourage them for better and greater educational aspiration.

\section{REFERENCES}

[1] Bamidele, T. O. (2016). Influence of sports on the academic performance of secondary school students in Akure South Local Government Area of Ondo State. Unpublished Dissertation University of Nigeria Nsukka, Faculty of Education.

[2] Dyer, A. M., Kristjansson, A. L., Mann, M. J., Smith, M. L., \&Allegrante, J. P. (2017). Sport Participation and Academic Achievement: A Longitudinal Study. American Journal ofHealth Behavior, 41(2), 179-185. https://doi.org/10.5993/AJHB.41.2.9

[3] Elaine, N. (2008) 'Education and sustainable development', Policy \& Practice: A Development Education Review, (6), 49-62.

[4] Haroona, Q., Hassan, S., Jin W. \& Tony, M. (2018). The Relation between Sports Participation and Academic Achievement: The Mediating Role of Parental Support and Self-Esteem .Journal of Human Psychology - 1(1), 29-42.

[5] Lemke, W. (2016).The Role of Sport in Achieving the Sustainable Development Goals. UN chronicle Vol. LIII No. 2

[6] Peter-Ajayi, O. M; Alade, T. T; Bamidele, T. O. \& Ariyo, A. O. (2019). Sports as a correlate of quality education and sustainable national development. Ikere Journal of Education. 19 (1). 29-34

[7] Stucko, M. A. (2018). Sport Participation and Academic Achievement in High School Athletes. Kinesiology, Sport Studies, and Physical Education SynthesisProjects.58.https://digitalcommons.brockport.edu/pes_sy nthesis/58

[8] UNESCO, (2017). Promoting the Role of Sport in achieving the Sustainable Development Goals 